\title{
PENERAPAN MODEL PROBLEM BASED LEARNING UNTUK MENINGKATKAN PEMAHAMAN SISWA PADA MATERI TRIGONOMETRI
}

\author{
Mohammad Jufri \\ SMA 1 Pademawu, Pamekasan \\ Email : mohammadjufri18@gmail.com
}

\begin{abstract}
Abstrak:
Penelitian ini bertujuan untuk mengetahui peningkatan pemahaman siswa pada materi trigonometri kelas XI-MIPA 2 SMA Negeri 1 Pademawu Tahun Pelajaran 2019/2020 melalui penerapan model problem based learning. Penelitian ini merupakan penelitian tindakan kelas dan dilakukan dalam dua siklus dengan beberapa tahapan yaitu: perencanaan, pelaksanaan, pengamatan, dan refleksi. Peneliti menggunakan metode observasi, angket, tes, dan wawancara. Aktivitas siswa mengalami peningkatan sebesar 0,06 yaitu pada siklus I diperoleh rata-rata sebesar 3,55 berkategori sangat baik dan siklus II diperoleh rata-rata sebesar 3,61 berkategori sangat baik. Respon siswa berkategori positif dengan peningkatan sebesar 3\% yaitu pada siklus I diperoleh persentase sebesar $90 \%$ dan pada siklus II diperoleh persentase sebesar 93\%. Hasil tes juga mengalami peningkatan sebesar $16,67 \%$, yaitu pada siklus I persentasenya sebesar $70 \%$ dan pada siklus II persentasenya sebesar $86,67 \%$. Perbaikan hasil tes pada siklus II dikatakan tuntas secara klasikal karena presentase yang diperoleh $\geq 85 \%$. Sehingga dapat dikatakan bahwa penerapan model problem based learning dapat meningkatkan pemahaman siswa pada materi trigonometri.
\end{abstract}

Kata Kunci: Model Problem Based Learning, Pemahaman Siswa, Trigonometri

\begin{abstract}
:
This study aims to determine the increase in students' understanding of trigonometry material for class XI-MIPA 2 SMA Negeri 1 Pademawu in the 2019/2020 academic year through the application of a problem based learning model. This research is a classroom action research and is carried out in two cycles with several stages, namely: planning, implementation, observation, and reflection. Researchers used the method of observation, questionnaires, tests, and interviews. Student activity increased by 0.06 , namely in the first cycle an average of 3.55 was obtained in the very good category and the second cycle obtained an average of 3.61 in the very good category. Student responses were categorized as positive with an increase of $3 \%$, namely in the first cycle the percentage was $90 \%$ and in the second cycle the percentage was $93 \%$. The test results also increased by $16.67 \%$, namely in the first cycle the percentage was $70 \%$ and in the second cycle the percentage was $86.67 \%$. The improvement of test results in cycle II is said to be classically complete because the percentage obtained is $85 \%$. So it can be said that the application of the problem based learning model can improve students' understanding of trigonometry material.
\end{abstract}

Keywords: Problem Based Learning Model, Student Understanding, Trigonometry

\section{Pendahuluan}

Tujuan pendidikan nasional berdasarkan Undang-Undang Dasar Negara Republik Indonesia adalah untuk mencerdaskan kehidupan bangsa. UU No. 20 tahun 2003 menyebutkan bahwa yang dimaksud dengan Pembelajaran adalah proses interaksi peserta didik dengan pendidik dan sumber belajar pada suatu lingkungan belajar. Proses interaksi belajar mengajar adalah inti dari kegiatan pendidikan. Sebagai inti dari kegiatan pendidikan, proses interaksi belajar mengajar adalah suatu upaya untuk mencapai tujuan pendidikan. Tujuan pendidikan tidak akan tercapai bila proses interaksi belajar mengajar tidak pernah berlangsung dalam proses pembelajaran. Guru dan siswa adalah dua unsur yang terlibat langsung dalam proses pembelajaran. Oleh karena itu disinilah peranan guru diperlukan untuk menciptakan 
interaksi belajar mengajar yang kondusif sehingga dapat meningkatkan prestasi belajar siswa.

Berdasarkan UU No. 20 tahun 2003 pasal 37 ayat 1 , menyebutkan Matematika merupakan salah satu mata pelajaran yang wajib diajarkan di sekolah menengah. Dalam dunia pendidikan khususnya pada zaman sekarang ini banyak perubahan dan perkembangan ilmu modern yang didasarkan pada teori-teori matematika. Namun, Belajar matematika selama ini masih kurang diamati oleh siswa, karena pada umumnya siswa beranggapan bahwa matematika adalah mata pelajaran yang sulit dan menakutkan, baik teori maupun konsep-konsep sehingga menyebabkan prestasi belajar matematika belum menunjukan hasil yang memuaskan. Salah satu materi yang diajarkan pada mata pelajaran matematika adalah Trigonometri.

Berdasarkan hasil observasi yang peneliti selaku guru pengajar di SMA 1 Pademawu khususnya kelas XI-MIPA 2, bahwa pembelajaran yang dilakukan lebih terpusat pada guru, sehingga siswa cenderung pasif. Hampir sebagian besar siswa mengaku bahwa mereka seringkali masih mengalami kesulitan untuk memahami pokok bahasan matematika yang dijelaskan oleh guru. Sebagian siswa hanya menghafal rumus tanpa mengetahui alur penyelesaian atau rumus awal yang dijadikan dasar dari permasalahan yang diberikan. Dan jika mereka diberikan soal dengan sedikit variasi yang membutuhkan penalaran lebih. Hanya beberapa siswa yang mampu menjawab dengan benar, itu pun hanya siswa yang memang tergolong lebih pandai dari siswa yang lain di kelasnya. Selain itu, banyak juga siswa yang mengaku bahwa ketika guru menjelaskan suatu pokok bahasan yang baru, terkadang mereka lupa akan inti dari pokok bahasan yang dijelaskan pada pertemuan-pertemuan sebelumnya. Beberapa kejadian yang telah dijelaskan tersebut menunjukkan bahwa pemahaman konsep siswa masih rendah.

Hasil penelitian Andriani (2017: 38) tentang analisis kesalahan konsep siswa dalam menyelesaikan soal trigonometri, mengemukakan bahwa siswa melakukan kesalahan konsep pada indikator yang digunakan di dalam penelitian tersebut, yaitu tidak mampu menyatakan ulang konsep, tidak mampu mengklasifikasikan objek-objek menurut sifat-sifat tertentu, tidak mampu memaparkan konsep secara berurutan, tidak mampu menyajikan konsep dalam berbagai bentuk representasi matematis, dan tidak mampu mengaplikasikan konsep atau algoritma pemecahan masalah. Hal tersebut dikarenakan beberapa faktor yang mempengaruhi kemampuan siswa dalam menjawab soal trigonometri. Salah satu diantaranya adalah kurangnya pemahaman konsep.

Akibat dari rendahnya pemahaman konsep adalah hasil belajar tidak memenuhi KKM. Untuk itu guru matematika harus mampu memilih dan menerapkan model pembelajaran yang tepat, sehingga siswa mampu memahami suatu konsep dalam pelajaran matematika. Salah satu model pembelajaran yang dapat digunakan sebagai alternatif tindakan untuk meningkatkan kemampuan komunikasi dan pemahaman konsep matematika siswa yaitu model pembelajaran Problem Based Learning. Problem Based Learning adalah model pembelajaran yang melibatkan siswa dalam memecahkan masalah nyata. Model ini menyebabkan motivasi dan rasa ingin tahu menjadi meningkat.

Berdasarkan hasil penelitian Angkotasan (2014: 18), menunjukkan bahwa model problem based learning merupakan model pembelajaran yang efektif dalam pembelajaran matematika serta memungkinkan siswa untuk terlibat aktif dalam kegiatan pembelajaran. Oleh karena itu, peneliti tertarik untuk menggunakan model problem based learning. Adapun tahap-tahap dalam proses pembelajaran Problem Based Learning yang dilakukan peneliti sebagai pemberi tindakan diantaranya memberikan orientasi tentang permasalahannya kepada siswa, peneliti mengorganisasikan siswa untuk meneliti, peneliti membantu investigasi mandiri dan kelompok, siswa dibantu dalam mengembangkan dan mempresentsikan hasil, siswa dibantu 
untuk menganalisis dan mengevaluasi proses mengatasi masalah.

\section{Metode Penelitian}

Jenis penelitian yang dipakai oleh peneliti adalah jenis Penelitian Tindakan Kelas (PTK). Kegiatan dilakukan di kelas XI-MIPA 2 SMA 1 Pademawu Tahun Pelajaran 2019/2020. Menurut Arikunto (2010: 129) Penelitian tindakan adalah salah satu strategi pemecahan masalah yang memanfaatkan tindakan nyata dalam bentuk proses pengembangan inovatif yang "dicoba sambil jalan" dalam mendeteksi dan memecahkan masalah. Penelitian tindakan ini dilakukan untuk meningkatkan efektifitas metode mengajar, pemberian tugas kepada siswa, penilain dan lain sebagainya. Menurut Arikunto (2010: 137) Penelitian tindakan kelas menggunakan model spiral dari kemmis dan taggart yang dikembangkan oleh Stephen Kemmis dan Robin MC Taggart yang terdiri dari siklussiklus dan masing-masing siklus menggunakan empat komponen tindakan, yaitu:

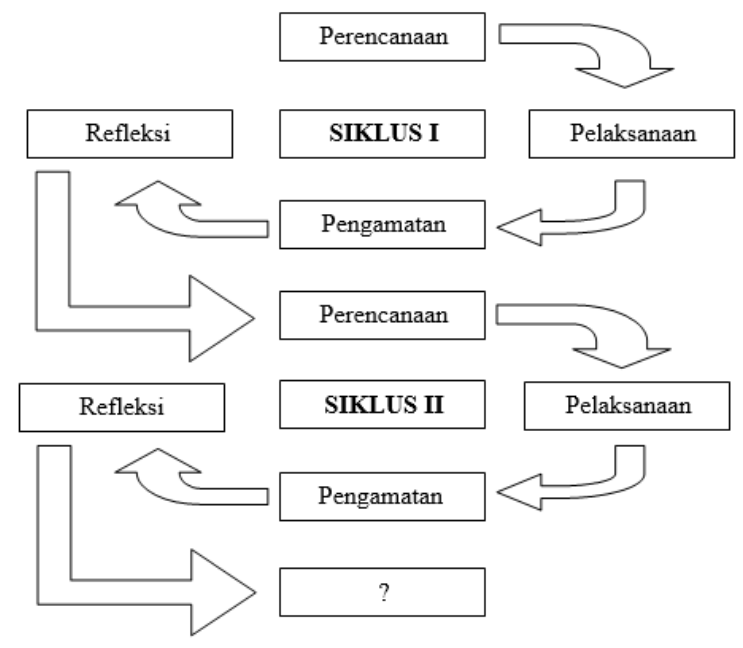

Gambar 1. Alur Siklus dalam Penelitian Tindakan Kelas

Kegiatan pelaksanaan dalam penelitian ini dijelaskan dalam 2 siklus sebagai berikut:

1. Siklus 1

a) Tahap Perencanaan (Planning).

Tahap ini terdiri dari: 1)

Membuat Rencana Pelaksanaan

Pembelajaran (RPP) tentang materi yang akan diajarkan sesuai dengan model problem based learning. RPP berguna sebagai pedoman guru dalam melaksanakan kegiatan pembelajaran kelas; 2) Menyusun dan mempersiapkan lembar observasi dengan bimbingan dosen; 3) Menyusun pedoman lembar angket untuk siswa. Lembar angket itu mempermudah peneliti untuk mengetahui bagaimana respon siswa terhadap kegiatan pembelajaran; 4) Mempersiapkan soal tes untuk siswa yang disusun oleh peneliti; 5)
Mempersiapkan kisi-kisi wawancara untuk siswa oleh peneliti. Wawancara digunakan untuk memperkuat hasil data tentang pemahaman siswa.

b) Tahap Tindakan (Acting)

Pelaksanaan tindakan yang dimaksud adalah melaksanakan pembelajaran sesuai rencana pembelajaran yang telah ditentukan. Adapun pelaksanaan kegiatan pada pembelajaran menggunakan Model Problem Based Learning adalah sebagai berikut: 1) Mengorientasikan siswa pada masalah; 2) Mengorganisasikan siswa agara belajar; 3) Memandu menyelidiki secara mandiri atau kelompok; 4) Mengembangkan dan menyajikan hasil kerja; 5) Menganalisis dan mengevaluasi hasil pemecahan masalah.

c) Tahap Pengamatan (Observing) 


\begin{abstract}
Observasi dilaksanakan selama proses pembelajaran di kelas berlangsung dengan menggunakan lembar observasi yag telah dibuat. Dalam hal ini ditekankan kepada siswa seberapa paham materi yang diterima oleh siswa dan seberapa jauh pelaksanaan tindakan yang dilakukan serta seberapa jauh tindakan yang sedang berlangsung dapat menghasilkan perubahan yang diinginkan. Setelah itu memberikan angket kepada siswa.
\end{abstract}

d) Tahap wawancara

Tahap wawancara dilakukan
setelah pembelajaran selesai.
Wawancara ini dilakukan terhadap
tiga narasumber berbeda untuk
memperkuat data yang diperoleh.

e) Tahap Refleksi (Reflecting)

Refleksi yang dilakukan pada tindakan siklus I adalah untuk melihat keseluruhan proses pembelajaran. Data yang diperoleh pada lembar observasi dianalisis, kemudian dilakukan refleksi.. evaluasi hasil tindakan yang telah dilakukan yaitu dengan cara melakukan penilaian terhadap proses yang terjadi, masalah yang muncul, dan segala hal yang berkaitan dengan tindakan yang dilakukan. Setelah itu mencari jalan keluar terhadap masalah-masalah yang mungkin timbul agar dapat dibuat rencana perbaikan pada siklus II.

2. Siklus 2

Siklus II dilaksanakan sebagai perbaikan dari siklus I, terutama jika terjadi kekurangan dalam perencanaan dan tindakan pada siklus I. Siklus II tidak dilaksanakan jika hasil penelitian kelas sudah sesuai dengan target ketuntasan belajar $70 \%$ perorangan dan $85 \%$ klasikal. Sebaliknya bila target ketuntasan belajar belum tercapai, siklus kedua akan dilaksanakan.

Adapun teknik pengumpulan data dalam penelitian ini peneliti menggunakan observasi, angket, tes, dan wawancara. Teknik pengumpulan data merupakan langkah yang paling strategis dalam penelitan, karena tujuan utama dari penelitian adalah mendapatkan data. Tanpa mengetahui teknik pengumpulan data, maka peneliti tidak akan mendapatkan data yang memenuhi standar data yang ditetapkan (Sugiono, 2012: 224). Untuk teknis analisis data, peneliti memperoleh data dengan kelayakan pengunaan alat peraga dakon matematika dalam pengajaran matematika, digunakan analisis data deskriptif dengan menghitung:

1) Observasi

Penilaian aktivitas siswa dalam pembelajaran berbasis masalah, dilakukan oleh peneliti dibantu teman sejawat dengan kriteria penilaian:

$$
\begin{aligned}
& \mathrm{A}=\text { dengan bobot } 4 \\
& \mathrm{~B}=\text { dengan bobot } 3 \\
& \mathrm{C}=\text { dengan bobot } 2 \\
& \mathrm{D}=\text { dengan bobot } 1
\end{aligned}
$$

Untuk mengetahui nilai aktivitas kelompok secara keseluruhan digunakan rumus:

2) Angket

$$
N A=\frac{\sum n}{\sum a}
$$

$$
\text { NA } \quad \text { Nilai akhir }
$$

$\mathrm{N}=$ = Nilai setiap aspek yang diamati

$$
\text { A }=\text { Aspek yang diamati }
$$

dengan kategori penentuan nilai akhir sebagai berikut:

$$
\begin{aligned}
& 0,00-1,49=\text { kurang } \\
& 1,50-2,49=\text { cukup } \\
& 2,50-3,49=\text { baik } \\
& 3,50-4,00=\text { sangat baik }
\end{aligned}
$$

Dari hasil penelitian yang berkaitan dengan rumusan masalah akan diolah menggunakan analisis deskriptif. Data penelitian ini adalah sebagai berikut:

Persentase respon siswa $=\frac{A}{B} \times 100 \%$ (Trianto, 2009: 243)

$\mathrm{A}=$ Proporsi siswa yang memilih iya

$\mathrm{B}=$ Jumlah siswa (responden)

Respon siswa dikatakan positif jika persentase rata-rata jawaban siswa $\geq 60 \%$. Sedangkan respon siswa dianggap negatif jika persentase ratarata jawaban siswa $<60 \%$. 
3) Tes

Tes dalam penelitian ini digunakan untuk mengukur kemampuan siswa dalam pemahaman konsep. Indikator yang menunjukkan bahwa pemahaman siswa meningkat dapat diketahui dengan cara membandingkan hasil analisis tes pada tiap-tiap siklus. Untuk menghitung ketuntasan belajar secara individu (KBI) peneliti menggunakan rumus sebagai berikut: $\mathrm{KBI}=\frac{\mathrm{T}}{\mathrm{T}_{t}} \times 100 \%$ (Trianto, 2009: 241)

$\mathrm{T}=$ Jumlah skor yang diperoleh

$\mathrm{Tt}=$ Jumlah skor maksimal

4) Wawancara

Wawancara digunakan untuk mengetahui tingkat pemahaman siswa. Wawancara dilakukan oleh peneliti menggunakan alat tulis dan rekaman serta pertanyaan dalam wawancara yang dilakukan berdasarkan indikator pemahaman sebagai berikut: 1) Mampu mengulang konsep; 2) Mampu Mengklasifikasikan objek sesuai dengan konsepnyaMampu membuat contoh dari konsep; 3) Mampu memodelkan soal terkait dengan konsep; 4) Mampu menentukan syarat dari suatu konsep; 5) Mampu menggunakan konsep untuk menyelesaikan soal; 6) Mampu mengaitkan konsep lain

Dengan kriteria penilaian sebagai berikut:
4 : Sangat Mampu
3 : Cukup Mampu
2 : Kurang mampu
1 : Tidak mampu sama sekali

Untuk mengetahui tingkat pemahaman siswa secara keseluruhan menggunakan rumus sebagai berikut:

Keterangan:

$$
N A=\frac{\sum n}{\sum a}
$$

$\mathrm{NA}=$ Nilai akhir

$\mathrm{N}=$ Nilai setiap aspek yang

diwawancarai

A = Aspek yang diwawancarai

Dengan kategori penentuan nilai akhir sebagai berikut:

$$
0,00-1,49=\text { kurang }
$$

$1,50-2,49=$ cukup

$2,50-3,49=$ baik

$3,50-4,00=$ sangat baik

\section{Hasil dan Pembahasan}

Hasil

\section{Tahap Pelaksanaan Siklus I}

I terdiri dari:

Kegiatan awal pembelajaran siklus

1) Tahap Perencanaan

Bahan pembelajaran dan penilaian dipersiapkan antara lain: RPP (fungsi trigonometri), lembar kerja siswa, lembar observasi siswa, lembar angket respon siswa, lembar tes, pedoman wawancara, dan daftar kelompok yang sudah dibentuk.

2) Pelaksanaan Tindakan

a) Kegiatan Awal Pembelajaran

Pada awal pembelajaran, peneliti mengucapkan salam dan keseluruhan siswa menjawab salam dari peneliti. Peneliti kemudian mengecek kehadiran siswa dengan melihat daftar absen dan membandingkannya dengan jumlah siswa di kelas. Peneliti kemudian merangsang keaktifan siswa dengan memberikan suatu permasalahan yang berhubungan dengan fungsi trigonometri. Pada tahap ini masih terdapat beberapa siswa yang tidak memperhatikan guru dan malah berbicara dengan temannya.

Peneliti kemudian menjelaskan tujuan pembelajaran dan memberikan apersepsi kepada siswa yaitu tentang materi trigonometri di kelas X. Pada tahap ini pun masih ada siswa yang tidak memperhatikan, namun secara keseluruhan siswa sudah memperhatikan. Dari sini peneliti meminta siswa untuk berkelompok dengan anggota yang telah ditentukan oleh peneliti sehingga membentuk kelompok yang heterogen. Tahap ini cukup memakan waktu karena siswa masih mengatur meja dan mencari anggota kelompoknya. Sebagian siswa juga ada yang memanfaatkan waktu tersebut untuk bergurau dengan temannya sehingga membuat pengelompokkan menjadi lebih lama. Peneliti ikut membantu siswa guna 
mengkondisikan kelas sehingga kegiatan inti bisa dimulai.

b) Kegiatan Inti Pembelajaran

Setelah mengelompokkan siswa, guru membagikan LKS yang berisi masalah untuk membantu siswa memahami fungsi trigonometri. Guru kemudian mengarahkan siswa untuk berdiskusi dengan kelompoknya guna menyelesaikan masalah yang ada di LKS. Perhatian siswa tertuju pada LKS yang diberikan oleh guru walaupun masih ada beberapa kelompok yang salah satu anggotanya tidak terlihat aktif dalam berdiskusi. Guru kemudian berkeliling dan menghampiri kelompok yang dimana terdapat anggotanya yang kurang aktif untuk mengajak siswa tersebut agar aktif dalam menyelesaikan masalah yang terdapat di LKS. Serta Guru berkeliling untuk membimbing siswa dalam menyelesaikan masalah.

Setelah diskusi selesai, guru meminta perwakilan kelompok untuk maju ke depan mempresentasikan hasil pengerjaannya. Ada tiga kelompok yang maju ke depan tanpa ragu-ragu namun hanya dua yang lancar dalam penyampaian hasil kerja kelompoknya. Sementara kelompok yang lain masih butuh arahan dari peneliti agar perwakilan kelompoknya maju mempresentasikan hasil.

Setelah presentasi selesai, guru memberikan soal latihan untuk dikerjakan siswa di papan tulis. Kebanyakan siswa tidak langsung mengacungkan tangan untuk maju ke depan mereka. Mereka meminta waktu untuk mengerjakannya di meja masingmasing. Namun setelah cukup lama masih belum ada yang mengacungkan tangan peneliti akhirnya memilih secara acak tiga orang yaitu dari siswa yang berkemampuan tinggi, sedang, dan rendah untuk maju ke depan. Siswa masih kesulitan untuk mengerjakan soal latihan yang diberikan. Dan seperti dugaan peneliti, siswa dengan kemampuan tinggi selesai terlebih dahulu disusul dengan siswa berkemampuan sedang sementara siswa yang berkemampuan rendah cukup kesulitan untuk menyelesaikan soal yang diberikan sehingga guru menyudahi pengerjaannya untuk dibahas bersama. Dari soal latihan yang diberikan, siswa berkemampuan tinggi bisa menjawabnya dengan benar. Siswa berkemampuan sedang masih mengalami kesalahan dalam pengerjaan terutama sisi dari suatu segitiga yang belum diketahui.

c) Kegiatan Akhir Pembelajaran

Pada akhir kegiatan guru meminta siswa untuk menyimpulkan materi pembelajaran yang sudah dipelajari. Pada awalnya hanya beberapa siswa yang menyimpulkan. Kemudian siswa lain mengikuti tapi malah membuat kelas menjadi gaduh. Peneliti kemudian meminta tiga orang untuk menyimpulkannnya. Peneliti mengambil siswa yang berkemampuan tinggi, sedang, dan rendah. Siswa berkemampuan tinggi bisa menyimpulkannya dengan lancar. Namun siswa berkemampuan sedang dan rendah masih gugup untuk menyimpulkan materi pembelajaran. Terutama siswa yang berkemampuan rendah sangat kesulitan dan beberapa kali berbisik kepada temannya untuk dibantu.

Tes untuk mengukur pemahaman siswa dilaksanakan selama 60 menit. Pada 10 menit pertama guru mengabsen siswa dan memberitahukan bahwa akan diadakan tes untuk melihat pemahaman siswa. Pada awalnya siswa mengerjakannya dengan tenang. Namun pada pertengahan jam siswa mulai terlihat tidak tenang terutama siswa yang tergolong berkemampuan sedang dan rendah.

3) Observasi

Penelitian ini menggunakan dua observer. Observer 1 dan 2 adalah guru mata pelajaran matematika kelas $\mathrm{X}$ SMA 1 Pademawu. Observer 1 mengamati aktivitas siwa pada kelompok 1, 2, dan 3. Sedangkan observer 2 mengamati aktivitas siwa pada kelompok 4, 5, dan 6 serta mengisi lembar observasi aktivitas siswa yang sudah disediakan oleh peneliti. Dari 
hasil observasi dan angket, peneliti akan mengambil keputusan untuk menyusun tindakan selajutnya.

Kegiatan siswa pada siklus I kurang aktif pada saat pembelajaran berlangsung. Pada kegiatan awal siswa kurang memusatkan perhatian pada apa yang disampaikan oleh peneliti, hal ini dikarenakan siswa berbicara dengan teman sebangkunya serta peneliti yang masih terasa asing bagi siswa sehingga komunikasi antara peneliti dengan siswa kurang. beberapa siswa masih kurang memahami materi yang dipelajari dikarenakan siswa masih kurang paham tentang fungsi trigonometri. Kekompakan di dalam kegiatan kelompok masih kurang.

Dan di dalam menyelesaikan soal masih banyak siswa yang meminta diberikan arahan secara terus menerus, meskipun diberikan arahan saat berkelompok. Siswa masih kebingungan dalam menentukan sisi-sisi dari suatu segitiga. ketika diberikan soal latihan, siswa kembali kesulitan dan keberanian siswa untuk bertanya masih kurang. Hal ini bisa dikarenakan siswa tidak percaya diri dengan hasil pekerjanya sekalipun sesudah peneliti cek hasilnya sudah benar. Siswa tidak terbiasa maju ke depan mempresentasikan hasil pekerjaannya. Sehingga pada tahap siklus I ini masih membutuhkan banyak perbaikan.

4) Wawancara

Wawancara digunakan untuk mengetahui sejauh mana pemahaman siswa. Wawancara dilaksanakan diluar jam pelajaran menggunakan alat tulis dan perekam suara. Dengan subjek wawancara terdiri dari tiga siswa masing-masing siswa berkemampuan tinggi (SKT), siswa berkemampuan sedang (SKS), dan siswa berkemampuan rendah (SKR).

Berdasarkan hasil wawancara dengan siswa berkemampuan tinggi, siswa berkemampuan sedang, dan siswa berkemampuan rendah pada siklus I, diperoleh hasil sebagai berikut:

Tabel 1. Skor Hasil Wawancara Siklus I

\begin{tabular}{ccccccccccc}
\hline & \multicolumn{8}{c}{ Indikator } \\
\cline { 3 - 8 } No. & Sampel & 1 & 2 & 3 & 4 & 5 & 6 & 7 & Rata-rata \\
\hline 1 & SKT & 4 & 4 & 3 & 4 & 4 & 3 & 4 & 3.71 \\
2 & SKS & 3 & 4 & 3 & 2 & 4 & 3 & 2 & 3.00 \\
3 & SKR & 2 & 2 & 2 & 1 & 2 & 2 & 2 & 1.86 \\
\hline \multicolumn{1}{c}{ Rata-rata keseluruhan } \\
\hline
\end{tabular}

Sumber data: hasil wawancara

Keterangan:

Indikator $1:$ Mampu mengulang konsep

Indikator 2 : Mampu Mengklasifikasikan objek sesuai dengan konsepnya

Indikator 3 : Mampu membuat contoh dari konsep

Indikator 4 : Mampu memodelkan soal terkait dengan konsep

Indikator 5 : Mampu menentukan syarat dari suatu konsep

Indikator 6 : Mampu menggunakan konsep untuk menyelesaikan soal

Indikator 7 : Mampu mengaitkan konsep lain

Berdasarkan hasil wawancara,

terlihat bahwa siswa berkemampuan tinggi sangat paham dalam menjelaskan kembali konsep, mengklasifikasikan objek sesuai konsepnya, memodelkan soal, menentukan syarat konsep, serta mengaitkan konsep tersebut dengan konsep lain, sementara siswa berkemampuan sedang terlihat

mampu dalam hal mengklasifikasikan objek sesuai konsep dan menentukan syarat konsep, tapi siswa berkemampuan rendah masih membutuhkan banyak bimbingan terutama dalam hal memodelkan konsep.

5) Refleksi

a) Kegiatan Awal Pembelajaran 
Pada kegiatan awal pembelajaran, siswa masih belum akrab dengan peneliti sehingga komunikasi antara siswa dengan peneliti terkadang masih canggung. Serta masih ada siswa yang tidak mendengarkan penjelasan peneliti dan malah bergurau dengan teman sebangkunya. Hal ini dikarenakan siswa tersebut memang tergolong nakal dan duduk bersama siswa yang juga tergolong nakal. Peneliti bermaksud menempatkan siswa tersebut dikelompok yang berbeda sehingga tidak mengganggu anggota kelompoknya. Observer 2 menyarankan peneliti untuk lebih banyak berkomunikasi dengan siswa baik pada saat pembelajaran maupun di luar pembelajaran sehingga siswa merasa lebih akrab dengan peneliti dan komunikasi antara pengajar dan yang diajar menjadi lebih baik.

Peneliti juga terkendala waktu pada saat pengelompokkan dikarenakan siswa tidak memiliki kesiapan dalam berkelompok. Hal ini bisa teratasi di siklus 2 dengan memberitahukan terlebih dahulu pada pertemuan sebelumnya tentang pengelompokan pada pertemuan berikutnya.

b) Kegiatan Inti Pembelajaran

Pada kegiatan inti masih terdapat siswa di dalam kelompok yang kurang aktif dalam membantu kelompoknya menyelesaikan masalah yang terdapat pada LKS. Dalam hal ini peneliti menghampiri kelompok tersebut dan mengajak setiap anggota kelompoknya untuk aktif dalam mengerjakan LKS.

Pada tahap diskusi kelompok juga masih banyak siswa yang belum memamahami sepenuhnya materi fungsi trigonometri yang belum diketahui menggunakan phytagoras. Hal ini bisa dikarenakan apersepsi yang diberikan peneliti kurang maksimal atau terburuburu dikarenakan terbatasnya waktu.

Pada tahap presentasi hasil kerja kelompok juga masih terdapat kelompok yang ragu untuk maju ke depan mempresentasikan hasil kerja kelompoknya. Serta pada saat pemberian latihan soal, siswa juga masih banyak yang ragu untuk maju ke depan, kecuali siswa yang berkemampuan tinggi.

c) Kegiatan Akhir Pembelajaran

$$
\text { Pada kegiatan akhir }
$$

pembelajaran, hanya siswa yang berkemampuan tinggi yang terlihat lancar dalam menyimpulkan materi fungsi trigonometri. Sementara siswa yang lain masih terlihat ragu-ragu dalam menyimpulkan. Pada saat pemberian tes, siswa juga masih belum bisa mengerjakannya dengan maksimal sehingga belum bisa mencapai KKM yang ditentukan yaitu 75 .

Hasil tes pada siklus I kurang memuaskan, hal ini terlihat dari nilai yang diperoleh siswa, masih banyak yang belum tuntas.

6) Rekomendasi

Guna memperbaiki kekurangankekurangan yang ada pada siklus I , maka akan dilakukan tindakan pada siklus II yang diharapkan dapat mengatasi kekurangan-kekurangan pada siklus I. Tindakan-tindakan tersebut, diantaranya: a) Memantapkan materi apersepsi pada awal kegiatan; b) Tidak mengubah anggota kelompok guna mempercepat pengelompokan kecuali siswa yang bermasalah; c) Memisahkan siswa yang membuat kegaduhan di dalam kelompok dengan menempatkan mereka di kelompok yang berbeda serta jarak kedua kelompok tersebut tidak berdekatan; d) Menghampiri dan menyemangati siswa yang tidak aktif di dalam kelompok serta kelompok yang ragu-ragu untuk maju ke depan mempresentasikan hasil kerja kelompoknya; e) Memancing siswa yang tidak aktif bertanya dengan menanyakan balik ke siswa tersebut.

\section{Tahap Pelaksanaan Siklus II}

Kegiatan awal pembelajaran siklus

II dilaksanakan sebagai berikut:

1) Tahap Perencanaan

Bahan pembelajaran dan penilaian dipersiapkan oleh peneliti, yaitu sebagai berikut: RPP (persamaan trigonometri), lembar kerja siswa, 
lembar observasi siswa, lembar angket respon siswa, lembar tes, pedoman wawancara, dan daftar kelompok.

Proses pembelajaran pada siklus II diharapkan berjalan lebih baik dari tindakan siklus I. Temuan-temuan yang diasumsikan menjadi penyebab tidak tercapainya target keberhasilan siklus I akan ditindak lanjuti pada pelaksanaan siklus II.

2) Pelaksanaan Tindakan

a) Kegiatan Awal Pembelajaran

Pada awal kegiatan di siklus II, peneliti memulai pelajaran dengan mengucapkan salam kemudian mengecek kehadiran siswa. Peneliti kemudian merangsang keaktifan siswa dengan memberikan suatu masalah terkait mencari nilai dari sudut istimewa. Setelah itu peneliti menjelaskan tujuan pembelajaran dan memberikan apersepsi kepada siswa yaitu fungsi trigonometri. Pada tahap ini keseluruhan siswa sudah mulai memperhatikan penjelasan guru terutama siswa yang pada siklus I kurang memperhatikan penjelasan guru. b) Kegiatan Inti Pembelajaran

Peneliti kemudian meminta siswa berkelompok untuk menentukan persamaan trigonometri. Tahap ini lebih cepat daripada siklus I karena pembagian kelompoknya sudah diberitahukan sebelumnya. Setelah guru memberikan arahan, siswa langsung memulai diskusi dengan anggota kelompoknya. Peneliti menghampiri masing-masing kelompok terutama siswa di dalam suatu kelompok yang pada siklus I terlihat kurang aktif. Peneliti mengajak siswa agar aktif dan membimbing siswa jika mengalami kesulitan.

Setelah diskusi selesai peneliti meminta siswa mempresentasikan hasil kerja kelompoknya. Pada siklus II ini setiap kelompok terlihat lebih siap ketimbang pada siklus I. Terutama kelompok-kelompok yang pada siklus sebelumnya kurang percaya diri dalam mempresentasikan hasil.

Peneliti kemudian memberikan soal latihan dan menunjuk siswa yang terdiri dari siswa berkemampuan tinggi, siswa berkemampuan sedang, dan siswa berkemampuan rendah. Dari ketiga siswa yang maju ke depan mengerjakan soal, siswa berkemampuan tinggi dan siswa berkemampuan sedang terlihat tidak memiliki kesulitan dalam mengerjakan soal. Untuk siswa berkemampuan rendah terlihat sempat tersendat dan meminta waktu tambahan, peneliti memberikan arahan secara tidak langsung dan meski memakan waktu cukup lama tapi siswa berkemampuan rendah bisa menyelesaikannya.

c) Kegiatan Akhir Pembelajaran

$$
\text { Pada kegiatan akhir }
$$

pembelajaran guru meminta siswa untuk menyimpulkan materi pembelajaran. Pada tahap ini siswa sudah bisa menentukan persamaan trigonometri.

Tes siklus II berlangsung selama 60 menit. Selama pengerjaan tes untuk siklus II, siswa sudah tidak membuat kegaduhan seperti di siklus I. pelaksanaan tes terlihat lancar. Setelah tes selesai guru menilai hasil tes siswa.

3) Observasi

Kegiatan siswa pada siklus II terlihat lebih aktif daripada siklus I pada saat pembelajaran berlangsung. Siswa terlihat serius dan bersemangat mengikuti proses pembelajaran. Pengamatan terhadap aktivitas siswa dilakukan oleh observser dengan menggunakan lembar observasi siswa. Lembar angket dibagikan kepada masing-masing siswa untuk diisi guna mengetahui respon siswa terhadap pembelajaran yang sudah diterapkan.

4) Wawancara

Wawancara digunakan untuk mengetahui sejauh mana pemahaman siswa. Wawancara dilaksanakan diluar jam pelajaran menggunakan alat tulis dan perekam suara. Dengan subjek wawancara terdiri dari tiga siswa masing-masing siswa berkemampuan tinggi (SKT), siswa berkemampuan sedang (SKS), dan siswa berkemampuan rendah (SKR).

Berdasarkan hasil wawancara dengan siswa berkemampuan tinggi, siswa berkemampuan sedang, dan siswa 
berkemampuan rendah pada siklus II,

diperoleh hasil sebagai berikut:

Tabel 2. Skor Hasil Wawancara Siklus II

\begin{tabular}{cccccccccc}
\hline & & \multicolumn{7}{c}{ Komponen } \\
\cline { 3 - 11 } No. & Sampel & 1 & 2 & 3 & 4 & 5 & 6 & 7 & Rata-rata \\
\hline 1 & SKT & 4 & 4 & 3 & 4 & 4 & 4 & 4 & 3.86 \\
\hline 2 & SKS & 3 & 4 & 3 & 3 & 4 & 3 & 3 & 3.29 \\
\hline 3 & SKR & 3 & 3 & 2 & 2 & 2 & 2 & 2 & 2.29 \\
\hline \multicolumn{8}{c}{ Rata-rata keseluruhan } \\
\hline
\end{tabular}

Keterangan:

Indikator $1:$ Mampu mengulang konsep

Indikator 2 : Mampu Mengklasifikasikan objek sesuai dengan konsepnya

Indikator 3 : Mampu membuat contoh dari konsep

Indikator 4 : Mampu memodelkan soal terkait dengan konsep

Indikator 5 : Mampu menentukan syarat dari suatu konsep

Indikator 6 : Mampu menggunakan konsep untuk menyelesaikan soal

Indikator 7 : Mampu mengaitkan konsep lain

Berdasarkan hasil wawancara, terlihat bahwa siswa berkemampuan tinggi bisa memenuhi indikator pemahaman dengan kriteria penilaian tergolong sangat baik, sementara siswa berkemampuan sedang juga tergolong sangat baik, dan siswa berkemampuan rendah pada siklus II ini sudah mengalami peningkatan dan masuk pada kategori sangat baik. Secara keseluruhan pembelajaran dengan penerapan model problem based learning pada pokok bahasan trigonometri di kelas XI-MIPA 2 SMA 1 Pademawu di siklus II ini terjadi peningkatan dari sebelumnya 2,86 menjadi 3,14.

5) Refleksi

a) Kegiatan Awal Pembelajaran

Refleksi dilakukan untuk menentukan apakah tindakan siklus II telah berhasil apa tidak. Berdasarkan hasil pengamatan yang diperoleh dari observer 1 dan observer 2, langkahlangkah pembelajaran yang telah direncanakan sudah dilakukan dengan baik. Tujuan pembelajaran untuk meningkatkan pemahaman siswa pada materi persamaan trigonometri dapat dikatakan berhasil baik dari segi proses maupun hasil belajarnya.

b) Kegiatan Inti Pembelajaran

Pada kegiatan inti di siklus II sama seperti di siklus I, yaitu tahap pengelompokan, tahap diskusi, dan tahap presentasi. Pada kegiatan inti sudah terjadi adanya perbaikan. Siswa yang sebelumnya tidak aktif di dalam diskusi kelompok mulai terlihat aktif. Pada saat presentasi hasil kerja kelompok, dari segi konsep siswa sudah lebih baik dalam menjelaskan materi persamaan trigonometri. Terutama perwakilan kelompok yang pada siklus I ragu-ragu untuk maju ke depan mempresentasikan hasil kerjanya.

Secara keseluruhan, proses pembelajaran pada kegiatan inti sudah mengalami pebaikan.

c) Kegiatan Akhir Pembelajaran

Hasil tes pada siklus II, siswa mampu menjawab secara maksimal dan siswa mampu mencapai KKM yang telah ditentukan yaitu 75. Sehingga pada siklus II telah mencapai ketuntasan hasil belajar. Hal ini terlihat dari ketuntasan belajar klasikal siswa yang diperoleh yaitu lebih dari $85 \%$. Hal ini dapat dilihat pada tabel berikut:

\section{Pembahasan}

Berdasarkan penelitian yang dilakukan, Penerapan model problem based learning untuk meningkatkan pemahaman siswa pada materi Trigonometri kelas XIMIPA 2 SMA 1 Pademawu tahun ajaran 2019/2020 selama dua siklus ditemukan bahwa: 
1) Aktifitas

Aktivitas siswa dalam mengikuti pembelajaran Penerapan model problem based learning untuk meningkatkan pemahaman siswa pada pokok bahasan trigonometri kelas XI-MIPA 2 SMA 1 PADEMAWU mengalami peningktatan sebesar 0,06 dengan nilai aktifitas siswa pada siklus I memiliki rata-rata 3,55 dengan kategori sangat baik dan pada siklus II memiliki rata-rata 3,61 dengan kategori sangat baik. Lebih jelasnya dapat dinyatakan dalam diagram berikut.

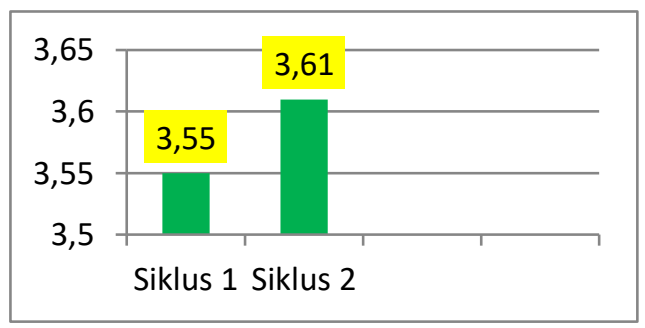

\section{Diagram 1. Hasil Observasi Aktivitas}

\section{Siswa}

\section{2) Respon}

Respon siswa terhadap Penerapan model Problem Based Learning untuk meningkatkan pemahaman siswa pada pokok bahasan trigonometri kelas XI-MIPA
2 SMA 1 Pademawu mengalami peningkatan sebesar 3\% dengan nilai angket respon siswa pada siklus I memiliki rata-rata $90 \%$ dengan kategori positif dan pada siklus II memiliki rata-rata 93\% dengan kategori positif. Lebih jelasnya dapat dinyatakan dalam diagram berikut:

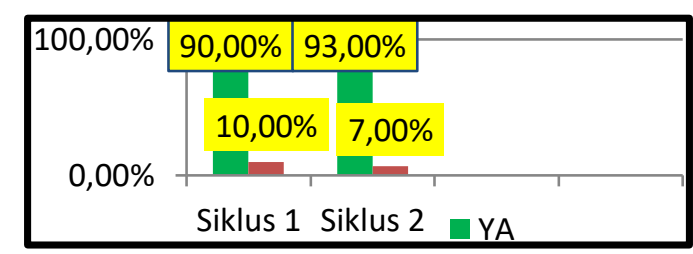

Diagram 2. Hasil Respon Siswa

3) Hasil Belajar

Hasil belajar siswa setelah diajar dengan menggunakan Penerapan model Problem Based Learning untuk meningkatkan pemahaman siswa pada pokok bahasan trigonometri kelas XI-MIPA 2 SMA 1 Pademawu mengalami peningkatan secara klasikal. Nilai rata-rata ketuntasan belajar klasikal pada siklus I sebesar $70 \%$ dan pada siklus II sebesar $86,67 \%$ yang artinya tuntas secara klasikal karena hasil presentase yang di dapat $\geq$ $85 \%$. Antara KBK silklus I dan siklus II mengalami peningkatan sebesar $16,67 \%$.

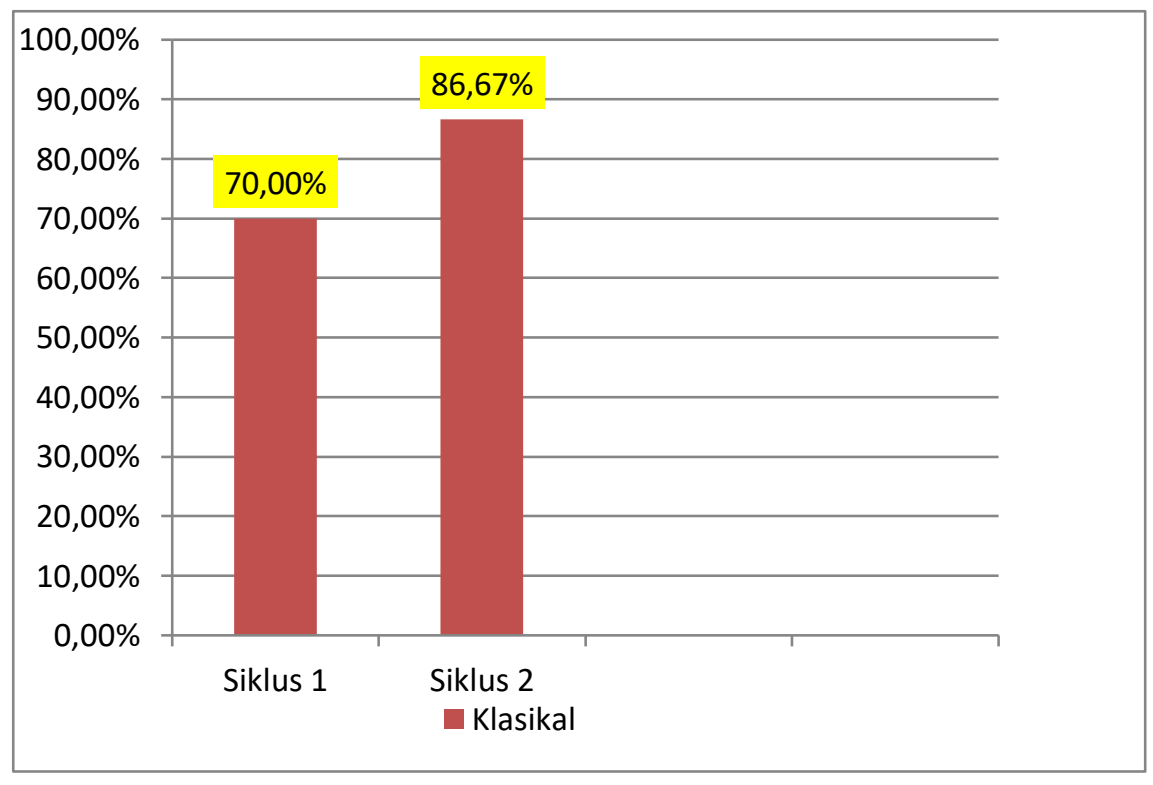

Diagram 3. Hasil Tes Siswa 
4) Pemahaman siswa

Pemahaman siswa setelah diajar menggunakan model Problem Based Learning untuk meningkatkan pemahaman siswa pada pokok bahasan trigonometri kelas X SMA 1 PADEMAWU berdasarkan hasil wawancara secara keseluruhan mengalami peningkatan sebesar 0,24 dan dengan siklus I memiliki nilai 2,9 dan siklus II memiliki nilai 3,14.

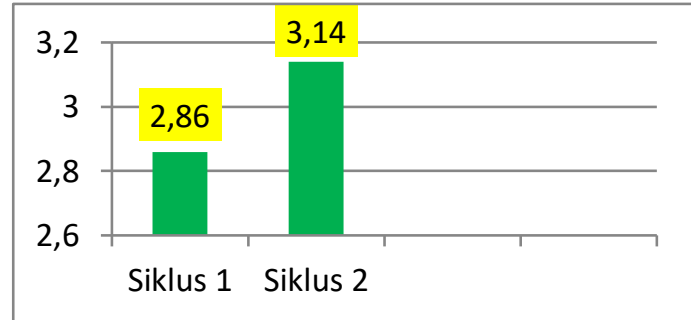

Diagram 4. Hasil Wawancara

\section{Keseluruhan}

Secara individual hasil wawancara dengan ketiga subjek di siklus I dengan ketiga subjek di siklus II juga mengalami peningkatan.

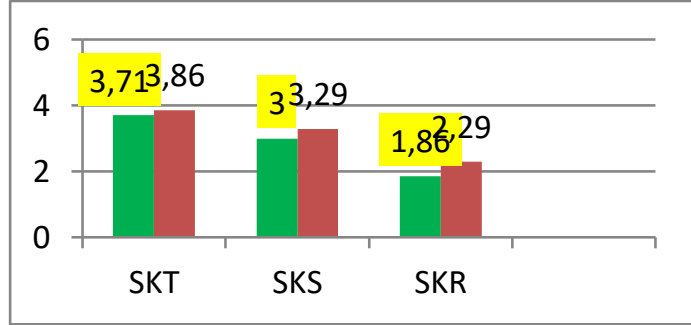

Diagram 5. Hasil Wawancara Individual

Berdasarkan hasil observasi, respon, tes, dan wawancara yang telah dilakukan diperoleh hasil sebagai berikut :

1. Analisis Data Hasil Observasi

Data yang diperoleh dari hasil observasi aktivitas siswa menunjukkan adanya peningkatan, hal ini terlihat dari hasil observasi aktivitas siswa yang terjadi peningkatan dari siklus I dan II. Pada siklus I diperoleh NA $=3.55$ yang berkategori sangat baik, sedangkan pada siklus II terjadi peningkatan yaitu NA = 3.61 yang berkategori sangat baik.

2. Analisis Data Hasil Angket Respon Siswa

Data yang diperoleh dari hasil angket menunjukkan adanya peningkatan, hal ini terlihat dari respon siswa yang meningkat dari siklus I ke siklus II. Pada siklus I diperoleh persentase sebesar $90 \%$ yang berkategori positif, sedangkan pada siklus II terjadi peningkatan menjadi 93\% yang berkategori positif.

3. Analisis Data Hasil Tes Siswa

Berdasarkan hasil data yang diperoleh, terdapat peningkatan nilai ketuntasan belajar siswa dari siklus I ke siklus II yaitu secara klasikal ketuntasannya $70 \%$ dengan rata-rata 74,8 pada siklus I dan siklus II secara klasikal ketuntasannya mencapai $86,67 \%$ dengan rata-rata 84,8 sehingga hasil belajar siswa meningkat dari siklus I ke siklus II. Pada siklus II dikatakan tuntas secara klasikal karena presentase yang didapat $\geq 85 \%$.

4. Analisis data hasil wawancara.

Dari hasil wawancara dengan siswa yang dilakukan pada siklus I dan siklus II juga menunjukkan adanya peningkatan. Dari nilai rata-rata keseluruhan 2,86 berkategori baik pada siklus I menjadi nilai rata-rata keseluruhan 3,14 berkategori sangat baik pada siklus II. Terjadi peningkatan sebesar 0,28 dari siklus I ke siklus II.

Aktifitas belajar matematika siswa pada pokok trigonometri di kelas XI-MIPA 2 SMA 1 Pademawu dalam penelitian ini mengalami peningkatan sebesar 0,06, dari rata-rata 3,55 pada siklus I dengan kategori sangat baik menjadi 3,61 pada rata-rata di siklus II dengan kategori sangat baik. Sedangkan respon siswa mengalami peningkatan sebesar 3\% dengan nilai angket respon siswa pada siklus I memiliki rata-rata 90\% dengan kategori positif dan pada siklus II memiliki rata-rata $93 \%$ dengan kategori positif.

Secara individu maupun klasikal, terdapat peningkatan dari siklus I ke siklus II. Pada siklus I siswa yang dinyatakan tuntas adalah 21 siswa dan 9 siswa dinyatakan tidak tuntas belajar secara individu. Untuk nilai tes secara klasikal pada siklus I belum mencapai target keberhasilan yaitu $70 \%$ siswa yang tuntas secara klasikal. Pada siklus II, 26 siswa dinyatakan tuntas dan 4 
siswa dinyatakan tidak tuntas belajar secara individu. Namun perbaikan pada siklus II membuahkan hasil yang cukup signifikan yaitu $86,67 \%$. Pada siklus II dikatakan tuntas secara klasikal karena presentase yang di dapat $\geq 85 \%$. Peningkatan dari siklus I ke siklus II sebesar $16,67 \%$ siswa yang tuntas secara klasikal.

\section{Simpulan dan Saran \\ Simpulan}

Berdasarkan hasil penelitian yang telah dilakukan, dapat disimpulkan bahwa aktifitas belajar matematika siswa pada trigonometri di kelas XI-MIPA 2 SMA 1 Pademawu dalam penelitian ini mengalami peningkatan sebesar 0,06 , dari rata-rata 3,55 pada siklus I dengan kategori sangat baik menjadi 3,61 pada rata-rata di siklus II dengan kategori sangat baik.

Berdasarkan hasil analisis dan angket respon terhadap penerapan model Problem Based Learning untuk meningkatkan pemahaman siswa pada pokok bahasan trigonometri kelas XI-MIPA 2 SMA 1 Pademawu dapat dilihat bahwa rata-rata presentase siswa pada siklus I yang menyatakan "iya" sebesar 90\% (positif). Sedangkan pada siklus II presentase siswa menyatakan "iya" sebesar 93\% (positif). Karena rata-rata presentase siswa menyatakan $\geq 60 \%$, maka menunjukkan bahwa respon siswa terhadap penerapan model Problem Based Learning untuk meningkatkan pemahaman siswa pada pokok bahasan trigonometri kelas XIMIPA 2 SMA 1 Pademawu ini adalah positif.

Berdasarkan data hasil belajar siswa pada pembelajaran menggunakan penerapan model Problem Based Learning untuk meningkatkan pemahaman siswa pada pokok bahasan trigonometri kelas XIMIPA 2 SMA 1 Pademawu menunjukkan adanya peningkatan baik ketuntasan secara individu maupun secara klasikal. Pada siklus I siswa yang dinyatakan tuntas adalah 21 siswa dan 9 siswa dinyatakan tidak tuntas belajar secara individu. Pada siklus II siswa yang dinyatakan tuntas adalah 26 siswa dan 4 siswa dinyatakan tidak tuntas belajar secara individu. Untuk nilai tes secara klasikal pada siklus I belum mencapai target keberhasilan yaitu hanya sebesar $70 \%$ siswa yang tuntas. Namun perbaikan pada siklus II membuahkan hasil yang cukup signifikan yaitu ketuntasan belajar klasikal meningkat sebesar 16,67\% dari siklus I menjadi 86,67\% pada siklus II secara klasikal. Artinya perbaikan pada siklus II dapat dikatakan tuntas secara klasikal karena presentase hasil tes siswa yang tuntas $\geq 85 \%$.

Berdasarkan data hasil wawancara dengan siswa, menunjukkan adanya peningkatan pemahaman siswa dengan nilai rata-rata pada siklus I sebesar 2,86 menjadi nilai rata-rata pada siklus II sebesar 3,14 . Terjadi peningkatan sebesar 0,28 dari siklus I ke siklus II.

\section{Saran}

Pembelajaran matematika menggunakan model Problem Based Learning dalam penelitian ini memberikan hal yang penting untuk diperhatikan. Untuk itu peneliti menyarankan beberapa hal berikut: 1) Bagi guru yang ingin menggunakan Problem Based Learning, disarankan agar benar-benar memahami dan mempersiapkan secara matang agar model ini benar-benar memeberikan manfaat kepada siswa; 2) Peneliti menganjurkan agar penerapan Problem Based Learning, dapat diterapkan pada pokok bahasan matematika yang lain, karena metode ini mendapatkan respon positif dari siswa; 3) Bagi pembaca, apabila ingin melakukan penelitian dengan permasalahan yang sama maka skripsi ini dapat dijadikan salah satu jurnal referensi.

\section{Daftar Pustaka}

Andriani, T,. dkk. (2017). Analisis Kesalahan Konsep Matematika Siswa dalam Menyelesaikan Soal Trigonometri Kelas X Tkj Smkn 1 Gempol Tahun Pelajaran 2016/2017. Pi: Mathematics Education Journal, 1(1). 34-39.

Angkotasan, N. (2014). Keefektifan Model Problem Based Learning Ditinjau Dari Kemampuan Pemecahan Masalah Matematis. Delta-Pi: Jurnal 
Matematika dan Pendidikan Matematika, 3(1). 11-19.

Arikunto, S. (2010). Prosedur Penelitian Suatu Pendekatan Praktik. Jakarta: PT Rineka Cipta.

Departemen Pendidikan Nasional. (2003). Undang-undang Nomor 20 Tahun 2003 Tentang Sistem Pendidikan Nasional. Jakarta: Depdiknas

Depdiknas. (2004). Peraturan Tentang Penilaian Perkembangan Anak Didik Nomor 506/C/Kep/PP/2004. Jakarta: Dirjen Dikdasmen Depdiknas.

Kementerian Pendidikan dan Kebudayaan. (2016). Materi Pokok Pelatihan Implementasi Kurikulum SMA Mata Pelajaran Matematika (Umum). Jakarta: Direktorat Pembinaan Sekolah Menengah Atas.

Lestari. (2016). Efektifitas Penerapan Model Problem Based Learning Ditinjau Dari Penalaran Matematis Siswa. Jurnal pendidikan Matematika Unila, 4 (5). 34-47.

Ngalim, Purwanto. (2006). Prinsip-prinsip dan Teknik Evaluasi Pengajaran. Bandung: PT. Remaja Rosdakarya.

Purwanto. (2013). Evaluasi Hasil Belajar. Yogyakarta: Pustaka Pelajar.
Sanjaya, W. (2009). Strategi Pembelajaran Berorientasi Standar Proses Pendidikan. Jakarta: Prenada

Santoso, B. (2016). Penerapan Model Problem Based Learning DalamPeningkatan Pembelajaran Matematika. Kalam Cendekia, 4(6.1). 713-718.

Siswanto. (2009). Theory and Application of Mathematics: For Grade $X$ of Senior High School and Islamic Senior High School. Solo: Tiga Serangkai.

Sudjana, N. (2010). Penilaian Hasil Proses Belajar Mengajar. Bandung: PT Remaja Rosdakarya.

Sugiono. (2012). Metode Penelitian Pendidikan: Pendekatan Kuantitatif, Kualitatif, dan $R \& D$. Bandung: Alfabeta

Trianto. (2009). Mendesain Model Pembelajaran Inovatif Progresif. Jakarta: Kencana Predana Media Group

Wulandari, B. (2013). Pengaruh Problem Based Learning Terhadap Hasil Belajar Ditinjau Dari Motivasi Belajar PLC Di SMK. Jurnal Pendidikan Vokasi, 3(2). 178-191.

Zarkasyi, W. (2016). Penelitian Pendidikan Matematika. Bandung: Refika Aditama. 